Title II-School Library Resources, Textbooks, and Other Instructional Materials

Library Services and Construction Act

Title I-Public Library Services

Title II-Public Library Construction

Title III-Interlibrary Cooperation

Title IVA-State Inst. Library Servs.

Title IVB-L. Servs. to the Phy. Handicapped

Higher Education Act

Title II-College Library Assistance and Library Training and Research

Part A-College Library Resources

Part B-Lib. Training, including Institutes -Research

Part C-LC Acquisition and Cataloging

"If no effort is made to override these recommended cuts, the prospects for even minimal aid for library resources for school, public and academic library users will be dismal indeed. There will be no funds at all for the school library program under Title II of the Elementary and Secondary Education Act. Half of the Title I funds for public library services and all of the Title II construction money will be withdrawn from programs partially supported by the Library Services and Construction Act. And half of the college library resources fund will be cut out of the HEA Title II-A program, leaving only enough money to make basic grants of $\$ 5,000$; training opportunities for librarians will be reduced by more than fifty per cent under Title II-B; and the Library of Congress acquisition and cataloging activities now assisted by the Title II, Part C program will be reduced by $\$ 2,856,000$."

\section{LIBRARY TECHNOLOGY PROGRAM MARKS 10TH ANNIVERSARY}

May marks the 10th anniversary of the Library Technology Program of the American Library Association. In a statement issued on the occasion, Forrest F. Carhart, Jr., director of the Library Technology Program, said, "I am proud of the accomplishments of the Library Technology Program over the past 10 years. LTP has, I believe, made many worthwhile contributions to the library community in the areas of testing, research, publishing, invention, standards and product evaluation. In a profession," he continued, "that 10 years ago had few guidelines or tools available to help the librarian make decisions on technical matters, cooperation.
$-0$

$\$ 23,209,000$

$\$ 17,500,000$

-0 -

$2,281,000$

$2,094,000$

$1,334,000$

$\$ 42,000,000$

$\$ 200,000,000$

$\$ 49,894,000$

$\$ 35,000,000$

$9,185,000$

$2,281,000$

$2,094,000$

$1,334,000$

$\$ 166,000,000$

$\$ 65,000,000$

$70,000,000$

$12,500,000$

$12,500,000$

$6,000,000$

$\left.\begin{array}{c}\$ 23,000,000 \\ 12,500,000 \\ 4,000,000 \\ 2,000,000 \\ 4,500,000\end{array}\right\}$

$\$ 42,606,000$

$25,000,000$

$8,250,000$

$2,000,000$

$7,356,000$
$\$ 114,100,000$

$75,000,000$

$28,000,000$

$11,100,000$

LTP has made a significant impact. Its work is now known in many countries of the world-as nearby as Canada, as distant as Australia. It gives assistance and information free-and freely-to all who seek its help, whether it concerns a $\$ 1,000$ expenditure on audiovisual equipment, or the manufacture of rustproof paper clips."

Carhart recalled that the idea of a technical project to serve the needs of the library world originated with the Council on Library Resources, Inc., and out of this idea grew a proposal that the Council undertake a researchtesting-standardization program in the field of library supplies, equipment, and systems. A grant of $\$ 136,395$ from the Council transformed the idea into a reality on May 1, 1959. "How well the idea and the reality have matured is seen today in the range of LTP's activities," continued Carhart. "They encompass an information service, a subscription service, the development of standards, product development and testing, publishing and international

"On this 10th anniversary of the Library Technology Program, I am particularly proud that we have been able to stimulate industry to bring to the market place products that answer the needs of librarians. We have done this in many ways, from speeches and informal talks, to marketing our own LTP inventions. I am proud, too, of Library Technology Reports, that every two months brings to subscribers much important information about products, and current technological news of interest to librarians. Its impact on the profession and on the library equipment and supplies manufacturing industry has been considerable, bringing with it an awareness by both groups of the need for better quality products and more intelligent purchasing. In another area," he 
stated, "we have made considerable progress in techniques of evaluating equipment and supplies in order to determine appropriate levels of performance and durability."

Carhart said that he was "proud of reaching the point where we support, with our own efforts, 57 per cent of our operating budget, and 29 per cent of research costs." At the beginning, 100 per cent of Library Technology Program support came from the Council on $\mathrm{Li}$ brary Resources, Inc. Carhart added, "I must acknowledge, gratefully, the assistance given by the Advisory Committee of the Library Technology Program. Over the years, we have benefited from both the sound advice of committee members, and their considerable goodwill. Finally," said Carhart, "I am proud of the Library Technology Program staff. From the beginning we have had a dedicated and intelli- gent staff always working in behalf of the Program. Together with the library profession itself, they have made success possible."

\section{CALLING ALL CONSTRUCTION!}

If you are building a new library or making substantial physical changes in your library, the Library Administration Division will appreciate receiving pictures, slides, floor plans, sketches, explanatory materials, and a copy of your written building program. These materials are needed in the buildings collection used by librarians, architects, and other building planners. For details about this collection write: Mrs. Ruth R. Frame, Executive Secretary, LAD, ALA, 50 E. Huron Street, Chicago, Illinois 60611.

\section{From Inside the DLP}

\section{By Dr. Kathafune M. Stokes}

College and University Library Specialist, Library Planning and Development Branch, Division of Library Programs, Bureau of Adult, Vocational, and Library Programs, U.S. Office of Education, Washington, D.C. 20202.

As usual, this piece is being written two months before you will read it. We are surrounded by stacks and boxes of applications for Title II-A (Higher Education Act) grants for library materials. The Grants Section, headed by Mrs. Catherine Robertson, has "logged in" 2,282 applications for basic grants (of up to $\$ 5,000), 1,808$ applications for supplementary grants (those that don't require matching), 670 applications for Special Purpose Type A grants, 70 for Type B, and 61 for Type C (for cooperative acquisitions by groups of libraries).

The corresponding figures for 1968 were 2,153 basic applications, 2,111 of which received grants; 1,550 supplemental applications, 1,524 of which received grants; 493 Special Purpose Type A applications, 19 of which received grants; 52 Special Purpose Type B applications, 9 of which received grants; and Special Purpose Type $\mathrm{C}$ applications from 173 libraries. Eleven combinations comprised of 65 libraries were awarded Type $\mathrm{C}$ grants.

All of these past and present statistics are set down to help you understand why you did or didn't receive a Title II-A award last month. The competition gets stiffer each year, but the $\$ 25,000,000$ appropriation has remained the same for three years. Next year the President's budget calls for half that amount.

The teams of evaluators have been with us for parts of two weeks rating the Special Purpose applications; the Grants Section is working through the basics; and Frank Stevens, Title II-A Specialist, Nathan Cohen, and I have almost finished checking the supplementary ones. We have had to make numerous phone calls, especially to universities which listed more than $30 \mathrm{PhD}$ programs instead of grouping them under the fields of graduate study noted in Appendix 2 of the application form. Sometimes we could classify them ourselves, but when Xerox copies of pages from a graduate catalog are the only clue, not even distinguishing master's programs from doctoral ones, we couldn't cope!

We are impressed again with the great need for resources in libraries at all academic levels, from the innumerable new community colleges to the universities with their proliferating new graduate programs.

Congratulations to those of you whose needs were great enough, and well documented enough, to receive the highest ratings. My sympathy to all the rest of you who need the money we don't have to distribute. 